\title{
Comparative application and optimization of different single-borehole dilution test techniques
}

\author{
Nikolai Fahrmeier $^{1} \cdot$ Nadine Goeppert $^{1} \cdot$ Nico Goldscheider ${ }^{1}$ \\ Received: 5 March 2020 / Accepted: 9 November 2020 / Published online: 5 December 2020 \\ (C) The Author(s) 2020
}

\begin{abstract}
Single-borehole dilution tests (SBDTs) are a method for characterizing groundwater monitoring wells and boreholes, and are based on the injection of a tracer into the saturated zone and the observation of concentration over depth and time. SBDTs are applicable in all aquifer types, but especially interesting in heterogeneous karst or fractured aquifers. Uniform injections aim at a homogeneous tracer concentration throughout the entire saturated length and provide information about inflow and outflow horizons. Also, in the absence of vertical flow, horizontal filtration velocities can be calculated. The most common method for uniform injections uses a hosepipe to inject the tracer. This report introduces a simplified method that uses a permeable injection bag (PIB) to achieve a close-to-uniform tracer distribution within the saturated zone. To evaluate the new method and to identify advantages and disadvantages, several tests have been carried out, in the laboratory and in multiple groundwater monitoring wells in the field. Reproducibility of the PIB method was assessed through repeated tests, on the basis of the temporal development of salt amount and calculated apparent filtration velocities. Apparent filtration velocities were calculated using linear regression as well as by inverting the one-dimensional (1D) advection-dispersion equation using CXTFIT. The results show that uniforminjection SBDTs with the PIB method produce valuable and reproducible outcomes and contribute to the understanding of groundwater monitoring wells and the respective aquifer. Also, compared to the hosepipe method, the new injection method requires less equipment and less effort, and is especially useful for deep boreholes.
\end{abstract}

Keywords Groundwater flow $\cdot$ Karst $\cdot$ Borehole techniques $\cdot$ Dilution test $\cdot$ Single-well method

\section{Introduction}

Investigation of boreholes with single-well methods plays an important role in hydrogeological aquifer characterization, especially in large and deep aquifers. Single-borehole dilution tests (SBDTs) are an easy-to-apply method for characterizing monitoring wells and boreholes and are based on the injection of a tracer into a borehole and the observation of the decreasing tracer concentration over time and depth. As a result, different flow regimes, in- and outflow horizons, and vertical

Published in the special issue "Five decades of advances in karst hydrogeology"

Nikolai Fahrmeier

Nikolai.Fahrmeier@kit.edu

1 Institute of Applied Geosciences, Division of Hydrogeology, Karlsruhe Institute of Technology (KIT), Kaiserstr. 12, 76131 Karlsruhe, Germany flow in a borehole can be identified (Halevy et al. 1967; Freeze and Cherry 1979).

When vertical flow components are negligible or absent, SBDTs can also be used to determinate horizontal filtration velocities and their variation over depth (Hall 1993; Lamontagne et al. 2002; Bernstein et al. 2007; Maurice et al. 2011). Unlike other methods, for example flowmeter logging, SBDTs can also identify very low velocities (West and Odling 2007); however, obtained filtration velocities are just valid for a small area around the groundwater monitoring well (GMW) or borehole, but, for example, can still be used to predict the spreading rate of a pollutant at a specific location.

If GMWs or boreholes are to be used as injection points for classical tracer tests, for example where natural swallow holes are absent, a dilution test should be carried out before the injection, in order to examine the degree of hydraulic connection to the aquifer (Fahrmeier 2016). Especially in heterogenic karst aquifers, it is important to check if a GMW or borehole is connected to the active drainage network or not (Goldscheider and Drew 2007). If GMWs or boreholes are used as sampling 
points for tracer tests, SBDTs should be carried out to detect inflow horizons in order to choose the best sampling depths (Fahrmeier 2016). Results of SBDTs can also be used to determine sampling depths in monitoring wells and can also deliver additional information for the interpretation of other data, for example hydrochemistry (Poulsen et al. 2019a). Information gained from SBDTs can be complemented by drilling logs, since there is often a relation between lithology and outflow. With image logs in uncased boreholes, it is possible to observe the size and nature of the fissures or conduits contributing to the flow (Maurice et al. 2012). Geophysical methods can also contribute to a better understanding of flow horizons (Williams et al. 2006). If SBDTs are carried out under pumped conditions, transmissivities and storativities can be assigned to individual layers or fractures (West and Odling 2007).

SBDTs have several other potential applications whereby on the basis of their degree of connection to the aquifer and reaction times, the suitability of GMWs as observation points, e.g. near a quarry or a waste disposal site, can be checked. Additionally, SBDTs in multiple GMWs or boreholes in one aquifer could be used to obtain the range of occurring velocities and so contribute to the understanding of the system. Furthermore, the effectiveness of well-cleaning can be checked by performing a test before and after the cleaning process.

Two complementary types of injection can be used for SBDTs. Uniform injections aim at an even tracer concentration throughout the whole saturated length to get information about groundwater flow within the entire GMW or borehole and identify major flowing features. However, it is difficult to conclusively identify vertical flows from uniform injection data. For this and also for a detailed investigation of a particular depth, point injections need to be used (Maurice et al. 2011). Both uniform and point injections can be conducted using different techniques and injection devices, for example hosepipes or funnels, as well as different tracers, and with or without the use of pumps in the injection well or a GMW nearby (Palmer 1993; Shafer et al. 2010; Maurice et al. 2011). Packers can be used to separate defined segments of a borehole for detailed investigation, which, however, may cut off vertical flow (Drost et al. 1968; Grisak et al. 1977; Lamontagne et al. 2002). Point injections can also be conducted as continuous injections, typically by means of pumping, which also allows a quantification of flow rates (Poulsen et al. 2019b). Table 1 provides an overview of examples from the literature with regard to tracer, methodology, and measuring devices. Early tests preferably used radioisotopes as tracers, because they allowed the determination of flow direction, using a scintillation counter (Drost et al. 1968; Klotz et al. 1979). Now mainly salts and fluorescence tracers (Halevy et al. 1967; Palmer 1993; Cook et al. 2001), as well as heated water (Banks et al. 2014; Bense et al. 2016; Leaf et al. 2012) or natural tracers, e.g. background conductivity (Love et al. 1999; Love et al. 2003), are commonly used.

However, most of the existing methods still need a lot of equipment like packers or pumps, and at least two people. For these reasons, a method with reduced effort, easier handling, and less costs is needed. This report introduces a simplified uniform injection method for SBDTs under natural gradients and compares it to the hosepipe injection method. In order to compare the different methods and to identify their advantages and drawbacks, several SBDTs were conducted under laboratory conditions by the use of a Plexiglas tube and in GMWs in the field. Since SBDTs are preferably conducted in uncased boreholes to gain undisturbed results (Maurice et al. 2011; Jamin et al. 2015), also the applicability in GMWs with slotted casing was tested.

Three typical and generalized examples of developments of tracer concentration over time and depth typical for uniform injections are shown in Fig.1a shows a higher outflow rate in the upper part and a lower outflow rate beneath that, which leads to a faster decrease of salt concentration in the upper section and a slower decrease in the lower part. This development could represent a change of lithology, for example loamy sand with low permeability in the lower part overlain by gravel with a higher flow rate. Figure $1 \mathrm{~b}$ shows two outflow zones, with the upper one having a slightly higher flow rate. This could correspond to a borehole in a fractured or karst aquifer which intercepts two preferential flow horizons with the same hydraulic head, while Fig. 1c shows an inflow at the top, then a downward movement followed by an outflow at the bottom. This example would be typical for a GMW or borehole in a karst aquifer that connects two different conduits with higher hydraulic head in the upper one, or a well in a recharge area with downward movement of groundwater.

\section{Materials and methods}

\section{Study site}

Field tests were performed in one of the largest groundwater protection areas in Germany Donauried-Hürbe (Fig. 2), which was established for the extraction wells of the Zweckverband Landeswasserversorgung (state water supply) which provides high-quality drinking water for around 3 million people. It has a total area of over $500 \mathrm{~km}^{2}$ and is located in the Federal State of Baden-Württemberg (Schloz et al. 2007).

The largest part of the study site, protection zone III, belongs to the eastern Swabian Alb, which is made up of Jurassic limestone with a thickness of up to $400 \mathrm{~m}$ that gently dips towards the southeast (Goldscheider 2005). In the south, the limestone is overlain by an increasing thickness of Tertiary Molasse sediments. In protection zone II, which corresponds to the Danube Valley, these sediments are up to $90 \mathrm{~m}$ thick. 
Table 1 Summary of selected dilution tests from literature in chronological order

\begin{tabular}{|c|c|c|c|c|}
\hline Author(s) & Tracer(s) & Injection & Methodology & Measuring method \\
\hline $\begin{array}{l}\text { Drost et al. } \\
1968\end{array}$ & $\begin{array}{l}\text { Radioisotopes }\left(\mathrm{NH}_{4}{ }^{82} \mathrm{Br}\right. \\
\left.{ }^{198} \mathrm{Au}, \mathrm{Na}^{131} \mathrm{I}\right)\end{array}$ & Point & $\begin{array}{l}\text { Apparatus with two packers, mixing spiral, } \\
\text { and injection syringe }\end{array}$ & Collimated scintillation-counter \\
\hline $\begin{array}{l}\text { Grisak et al. } \\
1977\end{array}$ & $\mathrm{NaF}$ & Point & $\begin{array}{l}\text { Borehole dilution apparatus with two packers } \\
\text { and mixing pump, tracer injection } \\
\text { with peristaltic pump }\end{array}$ & Ion-selective electrode \\
\hline Hall 1993 & $\mathrm{LiBr}$ & Uniform & $\begin{array}{l}\text { Hosepipe lowered into the borehole, filled } \\
\text { with tracer solution, and then pulled out }\end{array}$ & $\begin{array}{l}12 \text { ion-selective electrodes in dif- } \\
\text { ferent depths }\end{array}$ \\
\hline $\begin{array}{l}\text { Riemann } \\
\quad \text { et al. } 2002\end{array}$ & $\mathrm{NaCl}$ & Point & $\begin{array}{l}\text { Circulating tracer with a pump in } 2 \mathrm{~m} \text { section, } \\
\text { withdrawal } 5 \mathrm{~h} \text { after injection }\end{array}$ & Electrical conductivity sensor \\
\hline $\begin{array}{l}\text { Lamontagne } \\
\text { et al. } 2002\end{array}$ & $\mathrm{KCl}, \mathrm{KBr}$ & Point & $\begin{array}{l}\text { Recirculation of the water in a sealed } 0.5 \mathrm{~m} \\
\text { section with a peristaltic pump, injection with } \\
\text { an in-line tracer reservoir }\end{array}$ & In-line electrical conductivity cell \\
\hline $\begin{array}{l}\text { Williams } \\
\text { et al. } 2006\end{array}$ & $\mathrm{NaCl}$ & Uniform & $\begin{array}{l}\text { Hosepipe lowered into the borehole, filled with } \\
\text { salt solution and then removed }\end{array}$ & Electrical conductivity sensor \\
\hline $\begin{array}{l}\text { Bernstein } \\
\text { et al. } 2007\end{array}$ & 2,6-Difluorobenzoic acid & Point & $\begin{array}{l}\text { Injection with peristaltic pump, mixing in injection } \\
\text { well, forced gradient by pumping in a well } 3 \mathrm{~m} \\
\text { away }\end{array}$ & Not specified by author \\
\hline $\begin{array}{l}\text { West and } \\
\text { Odling } \\
2007\end{array}$ & $\mathrm{NaCl}$ & Uniform & $\begin{array}{l}\text { Hosepipe lowered into the borehole, filled with salt } \\
\text { solution and then removed, conducted near } \\
\text { a pumped well }\end{array}$ & Electrical conductivity meter \\
\hline $\begin{array}{l}\text { Pitrak et al. } \\
\quad 2007\end{array}$ & Brilliant Blue FCF, $\mathrm{NaCl}$ & $\begin{array}{l}\text { Uniform, } \\
\text { Point }\end{array}$ & Plastic hose with syringes for point injection & Photometric sensor \\
\hline $\begin{array}{l}\text { Brouyère } \\
\quad \text { et al. } 2008\end{array}$ & $\begin{array}{l}\text { Iodide, Lithium, Bromide, } \\
\text { Uranine, Sulforhodamine B }\end{array}$ & Uniform & $\begin{array}{l}\text { Circulation in the well with immersed pump, } \\
\text { tracer injection with peristaltic pump }\end{array}$ & Samples taken before reinjection \\
\hline $\begin{array}{l}\text { Gouze et al. } \\
2008\end{array}$ & Low salinity water, Uranine & Point & $\begin{array}{l}\text { Withdrawal (push-pull) tests in a segment } \\
\text { between two packers }\end{array}$ & $\begin{array}{l}\text { Electrical conductivity sensor, } \\
\text { optical sensor }\end{array}$ \\
\hline $\begin{array}{l}\text { Shafer et al. } \\
2010\end{array}$ & $\mathrm{NaCl}$ & Uniform & $\begin{array}{l}\mathrm{NaCl} \text {-solution injected with funnel and circulated } \\
\text { with pump for } 30 \mathrm{~min} \text { (extraction near the bottom, } \\
\text { reinjection on top) }\end{array}$ & $\begin{array}{l}\text { EC profiles with electrical } \\
\text { conductivity sensor }\end{array}$ \\
\hline $\begin{array}{l}\text { Maurice et al. } \\
2011\end{array}$ & $\mathrm{NaCl}$ & $\begin{array}{l}\text { Uniform, } \\
\text { Point }\end{array}$ & $\begin{array}{l}\text { Hosepipe lowered into the borehole, filled with salt } \\
\text { solution and then removed; point injection container } \\
\text { filled with salt and opened by a weight dropped } \\
\text { down the line }\end{array}$ & Electrical conductivity sensor \\
\hline $\begin{array}{l}\text { Leaf et al. } \\
\quad 2012\end{array}$ & Heated water & Point & $\begin{array}{l}\text { Water is extracted in the cased part of the well, } \\
\text { heated and reinjected in one or more depths }\end{array}$ & $\begin{array}{r}\text { Fiber optic distributed } \\
\text { temperature sensing }\end{array}$ \\
\hline $\begin{array}{l}\text { Banks et al. } \\
2014\end{array}$ & Heated water, $\mathrm{NaCl}$ & Uniform & $\begin{array}{l}\text { Heated water: Electrical heating cables increase } \\
\text { the temperature throughout the saturated zone } \\
\text { NaCl: Starting at the bottom, tracer solution is pumped } \\
\text { into the well through a hosepipe which is pulled } \\
\text { upwards at a constant rate }\end{array}$ & $\begin{array}{l}\text { Fiber optic distributed temperature } \\
\text { sensing, multi parameter probe }\end{array}$ \\
\hline $\begin{array}{l}\text { Libby and } \\
\text { Robbins } \\
2014\end{array}$ & Rhodamine WT & Uniform & $\begin{array}{l}\text { Tracer pumped through hosepipe, starting at the } \\
\text { bottom, then the pipe is pulled out, extraction } \\
\text { at the top to maintain the static well head, } \\
\text { afterwards mixing tool with propeller blades, } \\
\text { combined with slug test }\end{array}$ & $\begin{array}{l}\text { Optical probe attached to } \\
\text { multiparameter probe }\end{array}$ \\
\hline $\begin{array}{l}\text { Jamin et al. } \\
2015\end{array}$ & Uranine & Point & $\begin{array}{l}\text { Circulation between double packer system, } \\
\text { injection with an in-line tracer reservoir }\end{array}$ & Field fluorimeter \\
\hline $\begin{array}{l}\text { Read et al. } \\
\quad 2015\end{array}$ & Heated Water & Point & $\begin{array}{l}\text { Discrete volume of water heated with point heater, } \\
\text { combined with different extraction rates near the top }\end{array}$ & $\begin{array}{r}\text { Fiber optic distributed } \\
\text { temperature sensing }\end{array}$ \\
\hline $\begin{array}{l}\text { Poulsen et al. } \\
2019 b\end{array}$ & $\mathrm{NaCl}$ & Point & $\begin{array}{l}\text { Continuous point injection near one end of the well } \\
\text { combined with extraction at the other end }\end{array}$ & Multi parameter probe \\
\hline $\begin{array}{l}\text { Yang et al. } \\
2019\end{array}$ & KCl, Rhodamin WT & Point & $\begin{array}{l}\text { Isolation of a section with two packers, injection and } \\
\text { recirculation between the packers with pumps }\end{array}$ & $\begin{array}{l}\text { Electrical conductivity } \\
\text { sensor, field fluorimeter }\end{array}$ \\
\hline
\end{tabular}


a)

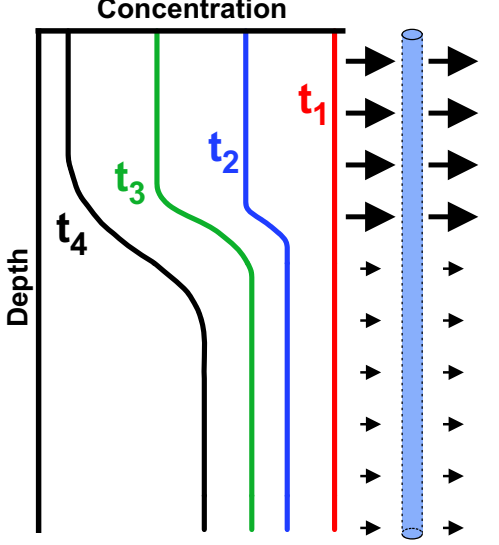

Fig. 1 Three typical patterns for the decrease of tracer concentration after uniform injections in monitoring wells (modified after Maurice et al. 2011). Curve $t 1$ shows the ideal concentration after injection, while $t 2$, t 3 and $t 4$ refer to increasing times after injection. a Shows higher flow in

On top of the Tertiary formations, up to $10 \mathrm{~m}$ of Quaternary gravels and overlying silt and clay sediments of up to $7 \mathrm{~m}$ are present (Kolokotronis et al. 2002; Schloz et al. 2007). This c)

\section{Concentration}

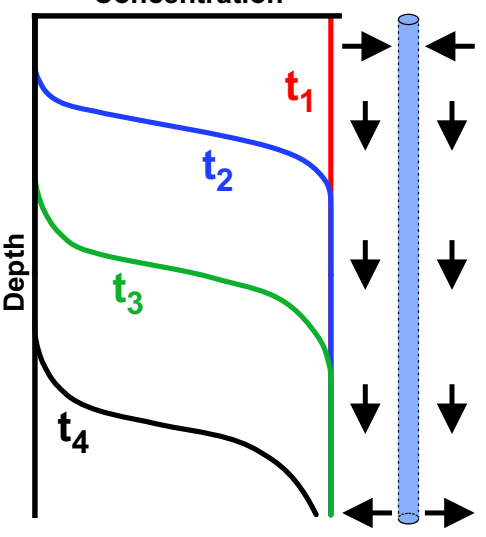

the upper part and lower flow in the lower part, $\mathbf{b}$ has two flow horizons one near the top, and one near the bottom; c shows vertical movement with inflow in the upper part and outflow near the bottom

geological setting leads to a complex hydrogeological system. The Jurassic limestones form a large and abundant karst aquifer, whose water flows to the southeast, where in some areas

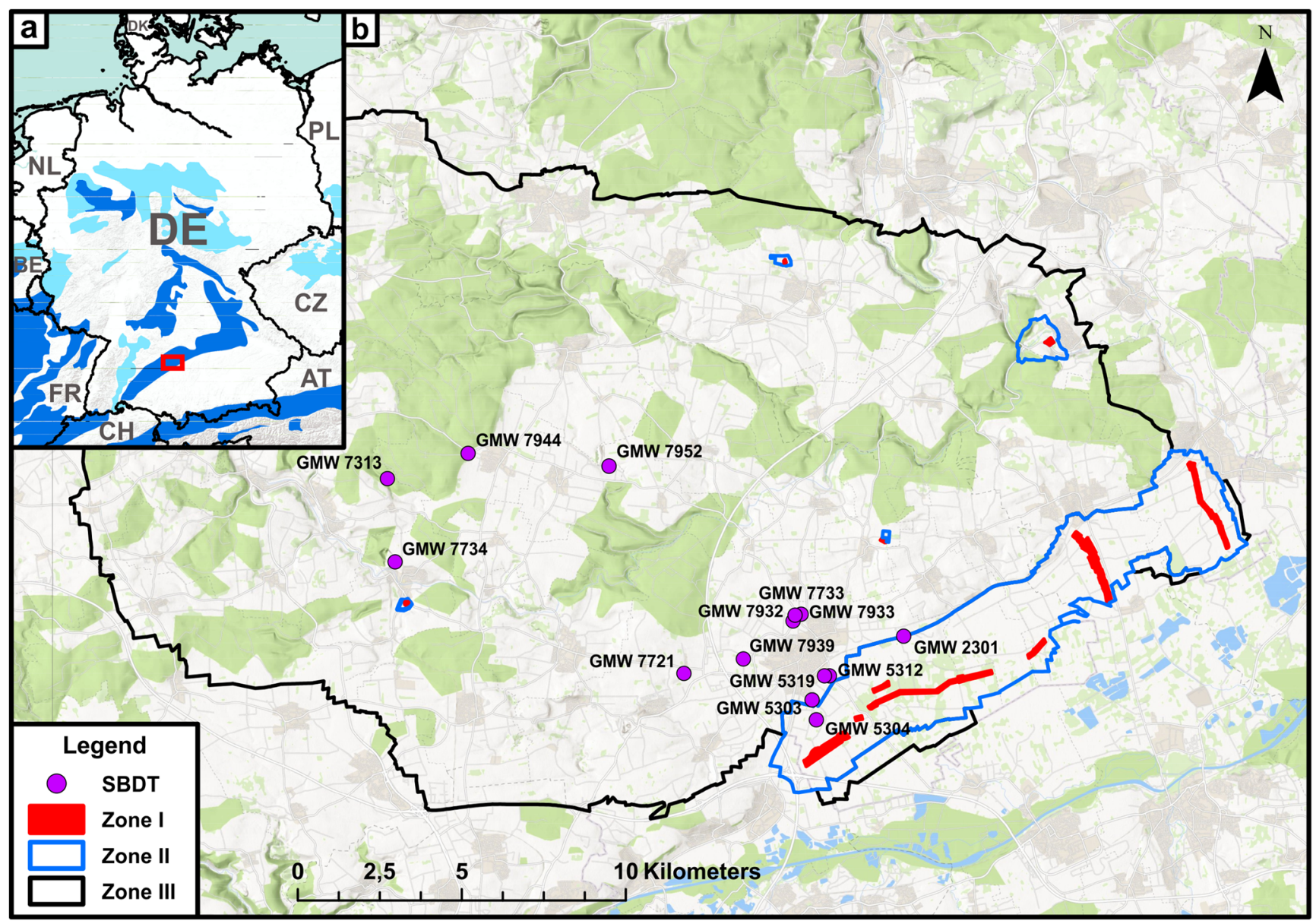

Fig. 2 a Location of the study site (red square) shown on a cut-out of the World Karst Aquifer Map (WOKAM, Chen et al. 2017; dark blue: continuous carbonate rocks, light blue: discontinuous carbonate rocks; country codes from ISO.org (2020). b Groundwater protection area "Donauried-Hürbe" with protection zones I, II and III (Schloz et al. 2007). Purple dots show GMWs in which SBDTs were conducted 
the Molasse is eroded, has just a small thickness, or is cut by fault zones. In those areas, water can flow from the karst into the gravel aquifer (Kolokotronis et al. 2002; Schloz et al. 2007).

More than 820 GMWs have been drilled in the study site since 1910 and equipped with slotted casing, 120 of them into the karst aquifer and 700 in the alluvial aquifer. Due to the large number of GMWs in two aquifers, SBTDs could be carried out under various conditions, with different depths to water level, saturated lengths, and outflow behaviors (Table 2). Within the scope of this work a total of 38 uniform injection SBDTs were conducted in 10 GMWs in the karst aquifer and in 4 GMWs in the gravel aquifer, using the permeable injection bag method and the hosepipe method. All SBDTs were conducted under undisturbed gradients and without the use of pumps. Additionally, four uniform injections were performed in a 6-m Plexiglas tube in the laboratory to test and compare the injection methods under fully controlled conditions, and to check for possible density effects during the experimental procedure.

\section{Injection methods}

\section{Hosepipe method}

Prior to every SBTD, the natural background of the used tracer within the GMW or borehole must be measured, and a calibration with the tracer and water from the respective GMW is required, to allow quantitative analyses. The most common method to obtain a uniform injection is the hosepipe method. A hosepipe is lowered into the GMW or borehole, with a weight attached at the end. Next, tracer solution is poured into the hosepipe, pushing the groundwater out of the lower end while replacing it with the tracer laden water (Maurice et al. 2011). The required amount of tracer solution can be calculated using the water level, well-depth and inner diameter of the used hosepipe. Injecting tracer in depth ranges with sealed casing can be avoided by pouring pure water into these sections of the hosepipe (West and Odling 2007). In conclusion, the hosepipe should be filled with tracer from the bottom to the water level or the upper end of slotted casing. The

Table 2 Summary of selected SBDTs in the karst aquifer (GMW 7733, 7721, 7313, 7939) and the alluvial aquifer (GWM 5303, 5304, 5312). PIB permeable injection bag; $H P$ hosepipe; n.d. not detected

\begin{tabular}{|c|c|c|c|c|c|c|c|c|c|}
\hline $\begin{array}{l}\text { GMW- } \\
\text { No. }\end{array}$ & $\begin{array}{l}\text { Water level below surface } \\
\text { (saturated length) }[\mathrm{m}]\end{array}$ & Date & $\begin{array}{l}\text { Injection } \\
\text { method }\end{array}$ & $\begin{array}{l}\text { Injection } \\
\text { Depth }[\mathrm{m}]\end{array}$ & $\begin{array}{l}\text { Number of } \\
\text { EC profiles }\end{array}$ & $\begin{array}{l}\text { Duration } \\
{[\mathrm{h}]}\end{array}$ & $\begin{array}{l}\text { Half- } \\
\text { time } \\
{[\mathrm{h}]}\end{array}$ & $\begin{array}{l}\text { Max. (mean) apparent fil- } \\
\text { tration velocity) }[\mathrm{m} / \mathrm{h}]\end{array}$ & $\begin{array}{l}\text { Vertical } \\
\text { flow }\end{array}$ \\
\hline \multirow[t]{5}{*}{7733} & $26.11(13.89)$ & 05.09 .16 & PIB & - & 9 & 22.5 & 0.78 & $0.21(0.09)$ & No \\
\hline & $26.49(13.51)$ & 07.04 .17 & PIB & - & 16 & 23.0 & 0.63 & $0.24(0.10)$ & No \\
\hline & $26.21(13.79)$ & 14.08 .18 & PIB & - & 27 & 22.1 & 0.83 & $0.23(0.09)$ & No \\
\hline & $26.58(13.42)$ & 08.07.19 & PIB & - & 19 & 22.9 & 0.70 & $0.23(0.10)$ & No \\
\hline & $26.59(13.41)$ & 09.07.19 & PIB & - & 18 & 12.1 & 0.65 & $0.24(0.10)$ & No \\
\hline \multirow[t]{5}{*}{7721} & $22.9(51.1)$ & 06.09 .16 & PIB & - & 7 & 22.4 & 2.73 & n.d. & Yes \\
\hline & $25.4(48.6)$ & 12.04 .17 & PIB & - & 13 & 22.4 & 0.48 & n.d. & Yes \\
\hline & $25.8(48.2)$ & 17.10 .18 & PIB & - & 20 & 21.1 & 1.12 & n.d. & Yes \\
\hline & $26.01(47.99)$ & 10.07.19 & PIB & - & 15 & 23.6 & 1.32 & n.d. & Yes \\
\hline & $26.01(47.99)$ & 11.07.19 & PIB & - & 12 & 9.1 & 1.50 & n.d. & Yes \\
\hline \multirow[t]{2}{*}{7313} & $59.40(14.35)$ & 07.09 .16 & PIB & - & 10 & $1,039.1$ & 8 & $0.05(0.01)$ & No \\
\hline & $65.27(8.48)$ & 12.07.17 & PIB & - & 27 & 820.5 & 111 & $0.04(-)$ & No \\
\hline 7939 & $8.40(20.60)$ & 14.08 .18 & PIB & - & 16 & 379 & 44 & $0.01(-)$ & No \\
\hline \multirow[t]{2}{*}{5303} & $7.68(8.32)$ & 21.08 .19 & PIB & - & 16 & 3.6 & 0.17 & n.d. & Yes \\
\hline & $7.78(8.22)$ & 29.08 .18 & HP & - & 11 & 1.4 & 0.23 & n.d. & Yes \\
\hline \multirow[t]{3}{*}{5304} & $6.58(6.42)$ & 31.07 .17 & PIB & - & 15 & 4.2 & 0.48 & n.d. & Yes \\
\hline & $6.68(6.32)$ & 16.08 .17 & HP & - & 14 & 7.1 & 0.35 & n.d. & Yes \\
\hline & $6.95(6.05)$ & 15.08 .18 & PIB & - & 24 & 6.1 & 1.40 & n.d. & Yes \\
\hline \multirow[t]{4}{*}{5312} & $7.24(8.51)$ & 19.07.17 & $\mathrm{HP}$ & - & 12 & 2.4 & 0.43 & n.d. & Yes \\
\hline & $7.24(8.51)$ & 20.07 .17 & PIB & - & 12 & 3.2 & 0.92 & n.d. & Yes \\
\hline & $7.40(8.35)$ & 02.08 .18 & PIB & - & 18 & 2.9 & 0.55 & n.d. & Yes \\
\hline & $7.53(8.22)$ & 24.08 .18 & PIB & - & 16 & 2.9 & 0.65 & n.d. & Yes \\
\hline
\end{tabular}


hosepipe is then pulled out, releasing the tracer into the surrounding water (Fig. 3a) To obtain a uniform injection, the hosepipe should be removed at a steady speed. The hosepipe method was used for six SBDTs during this study.Due to low costs and easy measurability, saline solutions are predominantly used as tracer for SBDTs, also common is the usage of fluorescence dyes. Within the scope of this work, all tests were conducted using sodium chloride $(\mathrm{NaCl})$ as tracer, due to easier handling compared to fluorescent dyes. Also, the outflow can be monitored easily by measuring depth profiles of electrical conductivity (EC); a TLC Meter Model 107 (Solinst Ltd.) and a CTD-Diver (Eijkelkamp Soil \& Water) were used during this study. Compared to fluorescent dyes, the use of $\mathrm{NaCl}$ requires larger amounts, which is why density has to be considered. Shafer et al. (2010) observed density effects during their test, but attained mean concentrations of more than $20 \mathrm{~g} / \mathrm{L}$ after mixing. Lamontagne et al. (2002) conducted several tests and found no density-driven movement while using low concentrations. They suggest to minimize the amount of salt, which leads to negligible density effects, by increasing the EC to a maximum of five times the natural background. Schincariol and Schwartz (1990) and West and Odling (2007) also came to the conclusion that low concentrations show no or only minor density effects.

\section{Permeable injection bag method}

As an alternative to a hosepipe filled with saline solution, the simplified method for uniform SBDTs uses solid $\mathrm{NaCl}$ filled in a permeable bag (e.g. nylon mesh). The bag is attached to a cable or rope and lowered into the GMW or borehole. During up- and downward movement within a selected depth interval or the whole saturated length, the salt dilutes and increases the electrical conductivity (Fig. 3b). Using a fine-meshed bag allows dilution but prevents leaks of undissolved salt. By moving the bag at a steady speed, a close-to-uniform distribution of $\mathrm{NaCl}$-concentration can be achieved.

To prepare an injection, basic information on the GMW or borehole (depth, diameter, water level) and the salt amount $\left(m_{\text {in }}\right)$ is needed. The latter can be calculated by using Eq. (1):

$m_{\text {in }}=V\left(\mathrm{EC}_{\mathrm{b}} x z\right)$

With $V$ being the water volume within the well casing or borehole, $\mathrm{EC}_{\mathrm{b}}$ the mean value of the natural background electrical conductivity, $x$ the factor by which the background EC should be increased, and $z$ the coefficient of a calibration with the used salt and water from the respective field site. During this work, salt amounts between 50 and $900 \mathrm{~g}$ were used. Having the calculated salt amount and the water volume within the casing or borehole, an approximation for the expected tracer concentration $\left(c_{\text {Exp }}\right)$ can be calculated (Eq. 2), with the radius $(r)$ and the saturated length $\left(d_{\text {sat }}\right)$ :

$c_{\mathrm{Exp}}=\frac{m_{\mathrm{in}}}{\pi r^{2} d_{\mathrm{sat}}}$
Fig. 3 Illustration of injections using a the hosepipe method and b the permeable injection bag method. Both methods aim at an uniform tracer concentration throughout the saturated zone a) Hosepipe

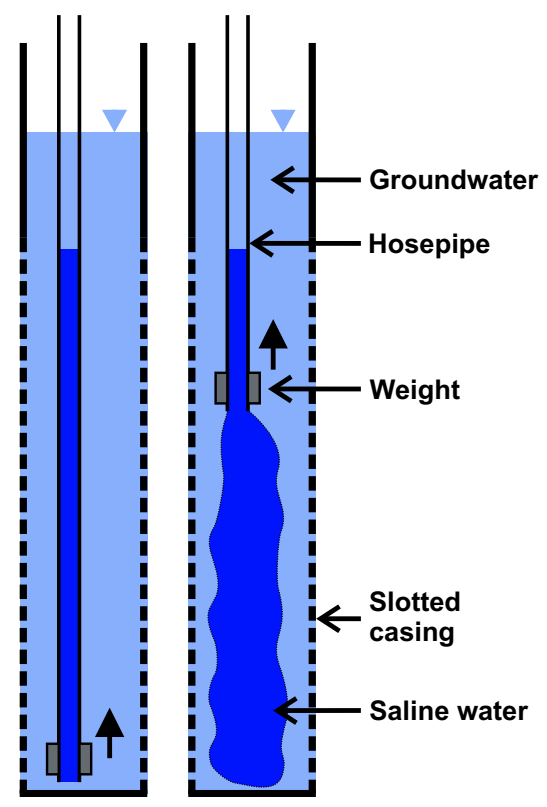

b) Permeable Injection Bag

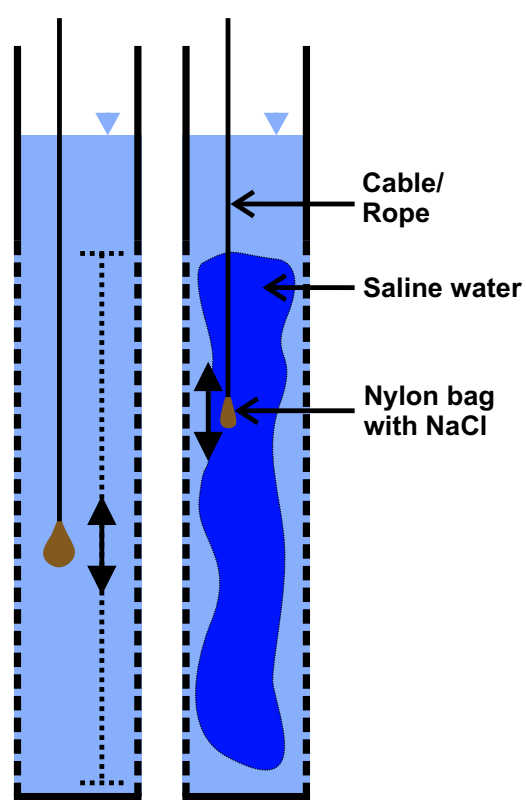


After each measurement, for each depth interval $\left(d_{1}-d_{2}\right)$, the remaining amount of salt within the casing $\left(m_{i}\right)$ can be calculated with Eq. (3):

$m_{i}=\frac{\left(\mathrm{EC}_{d 1}-\mathrm{EC}_{\mathrm{b} d 1}\right)+\left(\mathrm{EC}_{d 2}-\mathrm{EC}_{\mathrm{b} d 2}\right)}{2} z\left(d_{2}-d_{1}\right) \pi r^{2}$

\section{Filtration velocity}

The temporal development of tracer concentration obtained from uniform injections can be used to determine filtration velocities for every depth. The calculation of filtration velocities is based on the dilution versus time relation shown in Eq. (4), which is valid for nonreactive tracers, instantaneous injections and under the assumption that tracer dilution is only caused by horizontal groundwater flow (Freeze and Cherry 1979):

$\frac{d c}{d t}=-\frac{A v_{\mathrm{a}} c}{W}$

With tracer concentration $(c)$, time $(t)$, cross-section $(A)$, apparent filtration velocity $\left(v_{\mathrm{a}}\right)$, and volume of the well segment $(W)$. Rearrangement and integration then leads to Eq. (5) (Pitrak et al. 2007):

$\ln \left(c_{i}\right)=-\left(\frac{2 v_{\mathrm{a}}}{\pi r}\right) t_{i}+\ln \left(c_{1}\right)$

This can be solved by plotting the natural logarithm of tracer concentration versus time, which shows a linear trend if dilution is only caused by groundwater flow. As a result, Eq. (5) can be reduced to Eq. (6), where $m$ is the slope of the linear trend, which then allows the determination of $v_{\mathrm{a}}$ with Eq. (7) (Piccinini et al. 2016):

$m=-\left(\frac{2 v_{\mathrm{a}}}{\pi r}\right)$ $v_{\mathrm{a}}=\frac{m \pi r}{2}$

During the linear fitting, the first few concentration values have to be neglected in some cases as they are influenced by mixing effects and dispersion and thus falsify the value of $m$ (Pitrak et al. 2007).

As an alternative to linear regression, apparent filtration velocities can also be determined using the CXTFIT code from the STANMOD software package (Šimůnek et al. 1999). Piccinini et al. (2016) showed, that the apparent filtration velocity can be determined by inversing the $1 \mathrm{D}$ advection-dispersion equation. However, instead of using concentration values normalized to $C_{1}$, measured tracer concentrations were used as input values. Additionally, CXTFIT also delivers the dispersion for every depth (Piccinini et al. 2016).

The apparent filtration velocity then can be converted into filtration velocity. According to Halevy et al. (1967) $v_{\mathrm{a}}$ consists of filtration velocity $\left(v_{\mathrm{f}}\right)$, a correction factor $(\alpha)$ which compensates for the change of flow lines the well or borehole generates, and apparent flow velocities due to density effects $\left(v_{\mathrm{k}}\right)$, vertical currents $\left(v_{\mathrm{s}}\right)$, vertical mixing $\left(v_{\mathrm{m}}\right)$, and molecular diffusion $\left(v_{\mathrm{d}}\right)$ (Eq. 8):

$v_{\mathrm{a}}=\alpha v_{\mathrm{f}}+v_{\mathrm{k}}+v_{\mathrm{s}}+v_{\mathrm{m}}+v_{\mathrm{d}}$

In absence of vertical flow and density effects, and with neglectable influence by diffusion, Eq. (9) results (Halevy et al. 1967; Drost et al. 1968; Piccinini et al. 2016):

$v_{\mathrm{f}}=\frac{v_{\mathrm{a}}}{\alpha}$

The correction factor $\alpha$ (Eq. 10) is calculated with the inner radius of the filter tube $\left(r_{1}\right)$, the outer radius of the filter tube $\left(r_{2}\right)$, the radius of the borehole $\left(r_{3}\right)$ and the permeabilities of filter tube $\left(k_{1}\right)$, gravel filter $\left(k_{2}\right)$ and aquifer $\left(k_{3}\right)$ (Halevy et al. 1967; Drost et al. 1968):

$\alpha=\frac{8}{\left(1+\frac{k_{3}}{k_{2}}\right)\left\{1+\left(\frac{r_{1}}{r_{2}}\right)^{2}+\frac{k_{2}}{k_{1}}\left[1-\left(\frac{r_{1}}{r_{2}}\right)^{2}\right]\right\}+\left(1-\frac{k_{3}}{k_{2}}\right)\left\{\left(\frac{r_{1}}{r_{3}}\right)^{2}+\left(\frac{r_{2}}{r_{3}}\right)^{2}+\frac{k_{2}}{k_{1}}\left[\left(\frac{r_{1}}{r_{3}}\right)^{2}-\left(\frac{r_{2}}{r_{3}}\right)^{2}\right]\right\}}$

In homogenous gravel aquifers usually $\alpha=2$ can be assumed (Drost et al. 1968; Hall 1993; Pitrak et al. 2007). In more heterogeneous karst- or fractured aquifers, $\alpha$ can differ at a small scale, depending on the permeabilities of the surrounding rock (Drost et al. 1968).

\section{Results and discussion}

\section{Permeable injection bag SBDTs}

Using the PIB method, 34 dilution tests were carried out in different depth ranges and under varying conditions. The deepest GMW had a saturated length of $52 \mathrm{~m}$ and a total depth 
of $122 \mathrm{~m}$, while the shallowest GMW had $5 \mathrm{~m}$ of saturated length and a total depth of $8.5 \mathrm{~m}$. In eight GMWs, more than one SBDT was performed to confirm the results and check reproducibility. All tested GMWs are equipped with slotted casing, however, all major flowing features could be identified for each well. Due to the effect of filter gravel and slotted casing, it cannot be ruled out that not all smaller flowing features were detected. Table 2 shows the results of selected SBDTs carried out in karst and alluvial GMWs during this work using different injection methods. To avoid density effects, all tests aimed at increasing the background conductivity by a factor of 3-5 or 1,000-2,000 $\mu \mathrm{S} / \mathrm{cm}$, which corresponds to concentrations of $2-3 \mathrm{~g} / \mathrm{L} \mathrm{NaCl}$.

Figure 4 shows the results of a SBDT in karst GMW 7733, using the PIB method. This monitoring well has a depth of $40 \mathrm{~m}$ (all depths refer to the respective well cap) and the water level was at $26.59 \mathrm{~m}$. For this test, $200 \mathrm{~g}$ of $\mathrm{NaCl}$ were used, enough to increase the natural EC by almost five times. With
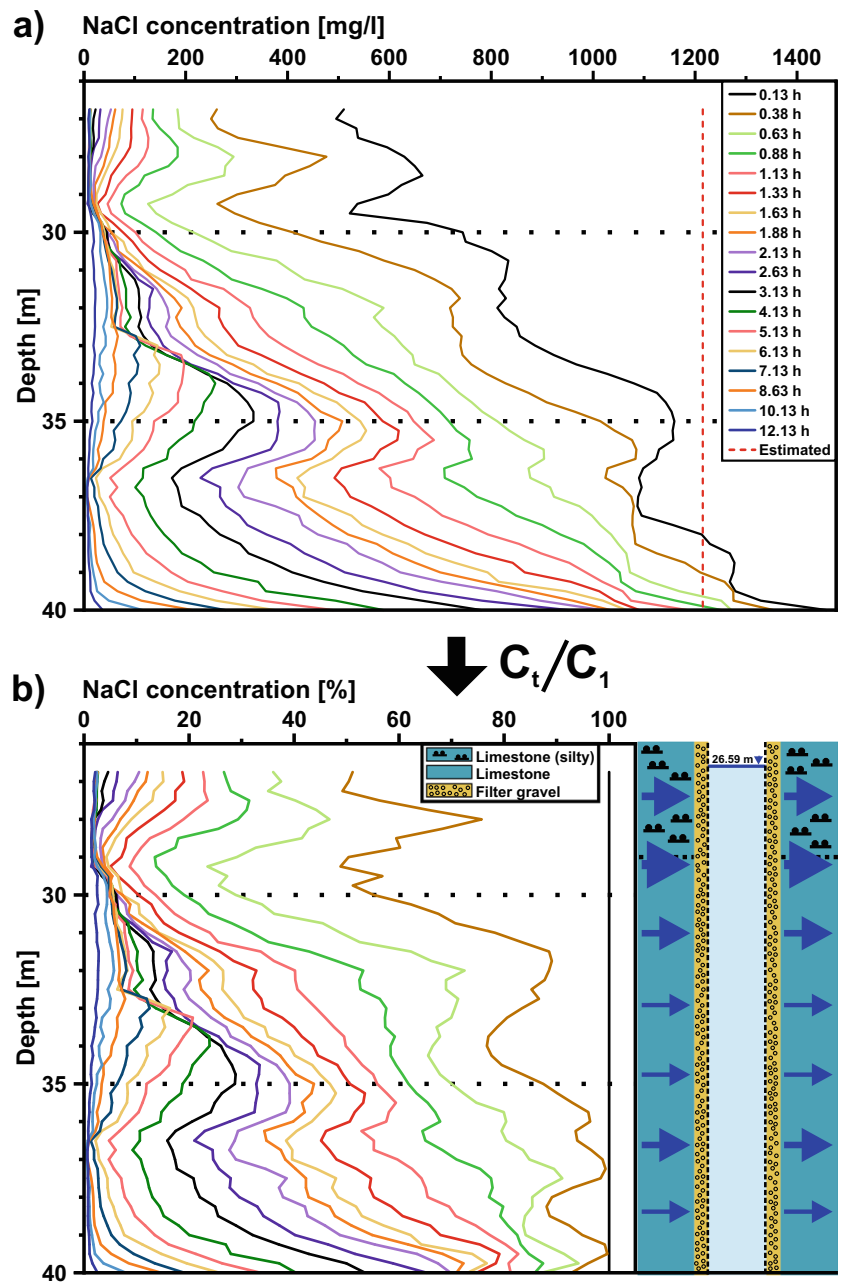

Fig. 4 Results of a SBDT using the PIB method in GMW 7733 (09.07.2019) including geology and identified outflow behavior. a Absolute values in $\mathrm{mg} / \mathrm{L}$, $\mathbf{b}$ normalized by dividing each profile by the first profile
Eq. (2) the estimated concentration was calculated $(1,215 \mathrm{mg} /$ $\mathrm{L}$, dashed red line). The injection took $8 \mathrm{~min}$, and was followed by an immediate measurement of an EC-profile. As can be seen in Fig. 4a, the estimated $\mathrm{NaCl}$-concentration is obtained only in the lower section of the GMW, while there is a significantly lower concentration in the upper part. This indicates a higher groundwater flow within the first meters and not an uneven injection, which would have resulted in concentrations above the expected value in other sections of the water column.

The fast decline in the upper part continues in the following measurements and is followed by a slower decrease between 31 and $35 \mathrm{~m}$. Around $36.5 \mathrm{~m}$, another zone with a slightly higher decrease suggests a flowing feature with higher groundwater flow. Near the bottom, the slowest decline of tracer concentration was observed. Altogether, the tracer amount decreases quickly, so that only very low tracer concentrations are measured $12 \mathrm{~h}$ after the injection, which indicates a good connection to the karst aquifer and the conduit system. GMW 7733 is one of the monitoring wells with the fastest outflow compared to other karst GMWs; the longest test in GMW 7313 took more than 6 weeks (Table 2).

In Fig. 4b, all EC-profiles are normalized by dividing each profile by the first measurement, to show the percentage decline of $\mathrm{NaCl}$ concentration for each depth. Normalized graphs are useful to compensate for uneven injections and ensure a better visualization of flowing features. In this case, both figures indicate the highest outflow around $29 \mathrm{~m}$. In this depth, the geology, obtained from the drilling log, shows a change of lithology from silty limestone to pure limestone. This chance of facies very likely favored karstification and the development of a preferential flow horizon.

For all tests the start of the injection was used as $t_{0}$, since outflow processes start immediately and so the first EC profile is already influenced by groundwater flow and an undisturbed injection profile is just hypothetical. Figure 5 shows the timeline of the SBDT in GMW 7733 on 09.07.2019. The first measurement $\left(t_{1}\right)$ always started directly after the injection. The first EC profiles were measured every $15 \mathrm{~min}$; later on, the intervals were increased to $2 \mathrm{~h}$ in four steps.

SBDT results from a karst monitoring well with vertical flow are shown in Fig. 6a. GMW 7721 has a total depth of $74 \mathrm{~m}$. On 06.09.2016, the water level was at $22.9 \mathrm{~m}$, resulting in a saturated length of $51.1 \mathrm{~m}$. Due to the depth, $875 \mathrm{~g}$ of $\mathrm{NaCl}$ was injected using the permeable injection bag method. The first profile shows a maximum concentration at $33 \mathrm{~m}$, indicating a nonperfect injection. However, flowing processes could still be observed and interpreted. It is noticeable that between measurements number 2 and 6 , maximum concentrations are almost constant and the shape of the curves is very similar, but with a steady downward offset. The missing decrease of $\mathrm{NaCl}$ concentrations in the middle part indicates missing horizontal outflow in the section between 40 and 
Fig. 5 Timeline of the SBDT in GMW 7733 on 09.07.2019. A total of 18 EC profiles were measured; one measurement took between 8 and $14 \mathrm{~min}$ (average $11 \mathrm{~min})$

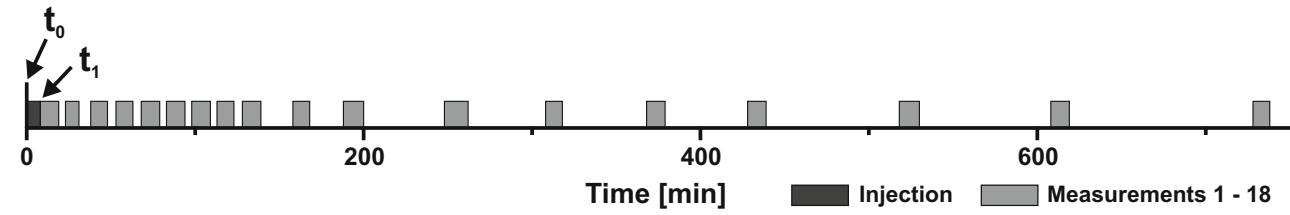

$70 \mathrm{~m}$. The vertical offset of concentration-profiles with little changes regarding the shape is a sign of vertical flow within the GMW. Using the vertical offset and time differences between the measurements, the vertical velocity can be estimated at $5.5 \mathrm{~m} / \mathrm{h}$. No tracer accumulation near the bottom is observed, indicating an outflow horizon at approximately $72 \mathrm{~m}$. This results in the interpreted flow paths shown in Fig. 6a. Twenty-two hours after injection, the salt plume reaches the bottom, signifying that GMW 7721 also has a good connection to the fracture and conduit network, resulting in fast tracer outflow.

GMW 7721 was cleaned with hydraulic pulsing on 11.04.2017, which removed black deposits in casing and filter

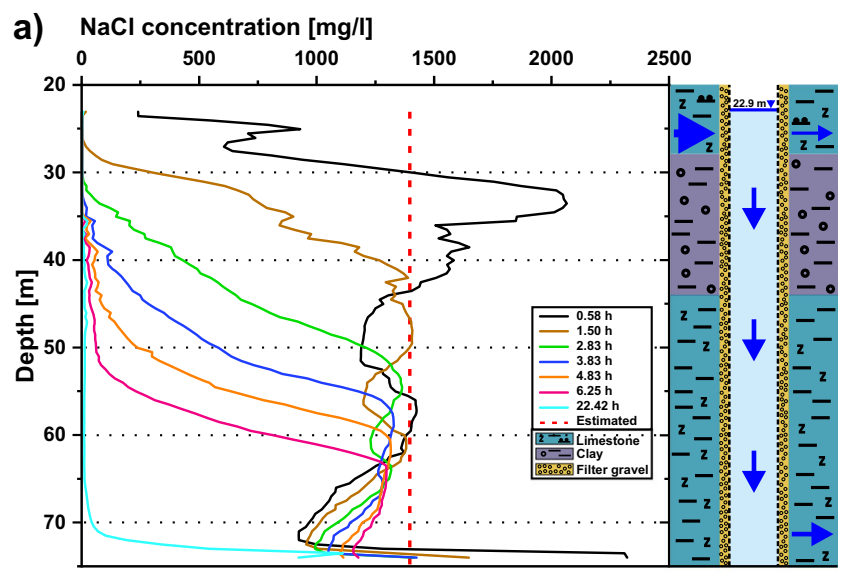

b) $\mathrm{NaCl}$ concentration [mg/l]

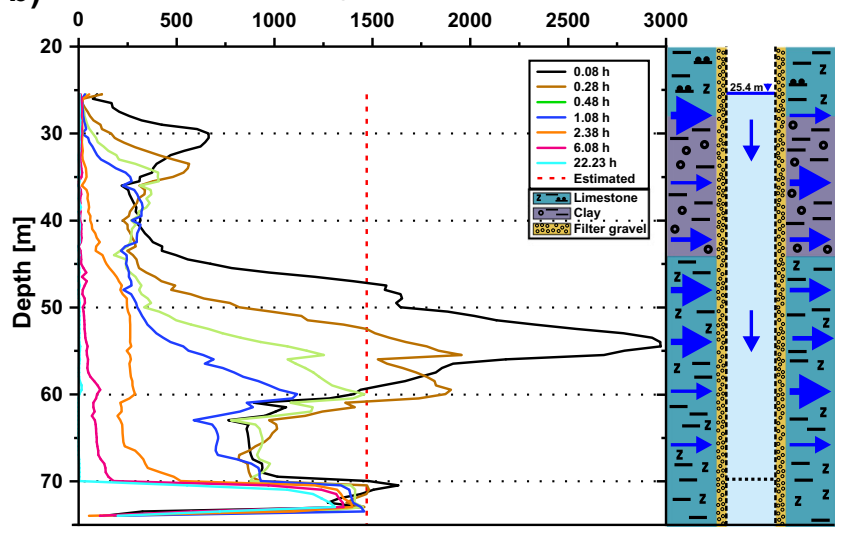

Fig. 6 Results of two SBDTs with the PIB method in GMW 7721. a Before cleaning, which shows that the monitoring well displayed a strong downward movement without significant decrease of the maximum value from measurements 2-6, which suggests vertical flow (06.09.2016). b After the cleaning on 11.04.2017, which shows that a complex combination of vertical flow and newly enabled horizontal flow can be derived from the concentration profiles (12.04.17) gravel. Figure $6 \mathrm{~b}$ shows the results of a dilution test conducted 1 day after the cleaning. $\mathrm{NaCl}$ concentrations decrease over the whole saturated length caused by horizontal flow, which is no longer blocked by deposits. Also, vertical flow is substantially lower, and between 70 and $74 \mathrm{~m}$, almost no decrease of tracer concentration is observed. During the cleaning, some of the deposits were not removed but sank to the bottom, where they partially block the outflow near the bottom leading to a weaker vertical flow component. Also, the water level during the second SBDT was $2.5 \mathrm{~m}$ lower, which leads to smaller hydraulic head differences and therefore less vertical flow.

In addition to the newly occurring horizontal flow, success of the cleaning can also be confirmed with the determined half-time, the time span until $50 \%$ of tracer has flowed out of the respective GMW. Before the cleaning, it took $2.7 \mathrm{~h}$ until the salt amount in the water column was half of the injected amount, afterwards only $0.5 \mathrm{~h}$. These results were confirmed by another four SBDTs in GMW 7721. However, 16 months after the cleaning, half-time increased again to $1.1 \mathrm{~h}$ and, after 25 months, to $1.3-1.5 \mathrm{~h}$ (Table 2 ), which indicates new deposits in the filter gravel or the slotted casing. These results show that the permeable injection bag method can also be used to check the effects of well cleaning.

For all uniform injections, the tracer amount within the casing was calculated for each measurement using the concentrations from each depth (Eq. 3). This allows a characterization of the overall behavior of the well and also a better comparison of different sites. Figure 7 displays the decline of

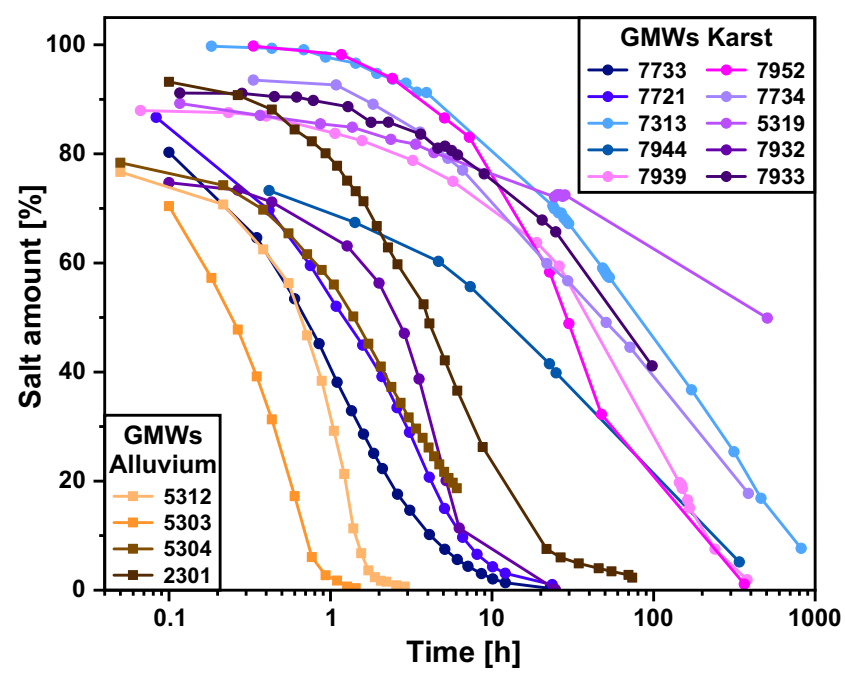

Fig. 7 Development of salt amount with regard to the injection amount for each tested GMW in karst and alluvium. For the eight monitoring wells with multiple SBDT-results, just one curve is shown 
$\mathrm{NaCl}$ amount for all tested GMWs. Half-times vary between 1 and $\sim 1,000 \mathrm{~h}$, confirming major differences in groundwater flow in the study site. GMWs in the alluvium aquifer tend to show a faster outflow than GMWs in the karst aquifer, but individual karst GMWs have a good connection to the conduit system, and thus also possess a rapid decline. In contrast, some karst GMWs show a weak and long-lasting decrease indicating slow advection (Table 2).

\section{Reproducibility}

The reproducibility of the permeable injection bag method was examined based on two aspects, the temporal development of salt amount and apparent filtration velocities. Repeated tests in several GMWs, conducted under similar hydraulic conditions, were compared with regard to the decrease of salt amount in the well. Figure 8 shows salt amount versus time for 14 SBDTs in three different monitoring wells. The three GMWs are clearly separated from each other, while curves from the same site are almost identical and thus are a strong indicator for the reproducibility of the PIB method. Small differences can be explained with changing injection times due to different salt amounts, varying grain sizes, and slight changes in the water levels. Since GWMs 7733 (karst) and 5303 (alluvial) both include one SBDT with the hosepipe method, these results also indicate the reproducibility of SBDTs in general, irrespective of the injection method used.

Moreover, reproducibility was assessed by comparing velocities of repeated tests in GMW 7733, which shows no vertical flow and thus allows the calculation of apparent filtration velocities $\left(v_{a}\right)$ with both methods described in section

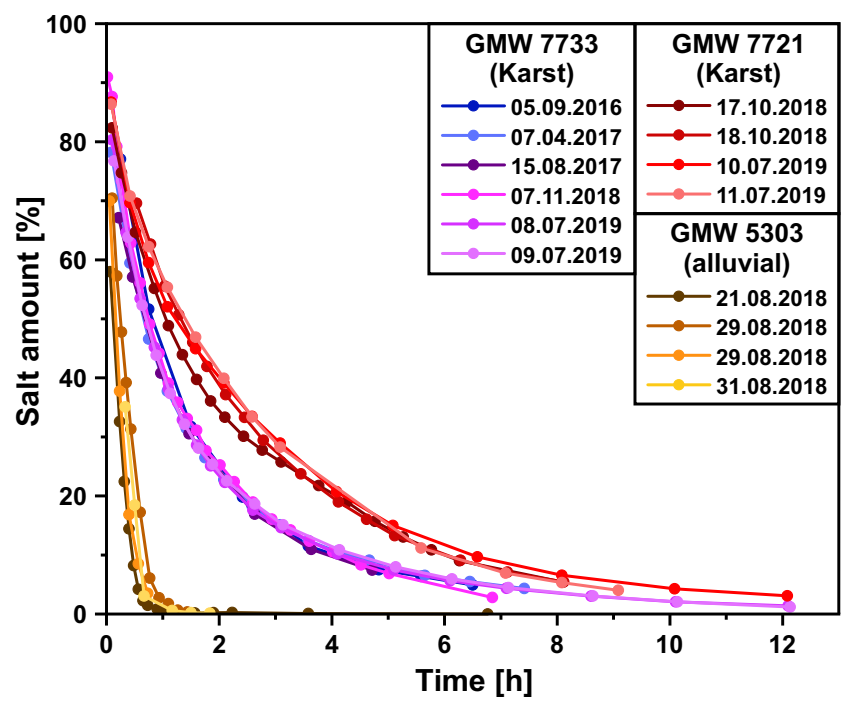

Fig. 8 Development of salt amount for repeated SBDTs in GMW 7733 $(n=6)$, GMW $7721(n=4)$, and GMW $5303(n=4)$ conducted under similar water levels. GMW 7733 (15.08.17) and GMW 5303 (29.08.2018) each include one SBDT with the hosepipe method. The conformity for each GMW demonstrates the reproducibility of SBDTs and especially the permeable injection bag method
'Filtration velocity'. Due to missing permeability values of the surrounding limestone, the correction factor $\alpha$ (Eq. 10) could not be calculated and thus also no filtration velocities $\left(v_{f}\right)$. Still, the comparison of the different SBDTs is possible with the determined $v_{a}$-values.

Figure 9 shows the mean apparent filtration velocities and the standard deviation for each depth gained from six SBDTs in GMW 7733 between 09/2016 and 07/2019 under similar hydraulic conditions. Both methods produced similar velocity profiles for each test, resulting in a low standard deviation, which also proves the reproducibility of the PIB method. A comparison of the two methods of determination shows a good accordance. Plotting filtration velocities obtained from CXTFIT versus filtration velocities from linear regression results in $R^{2}=0.996$ and a $=1.009$. With these minor differences, both methods are applicable for analyzing uniform SBDTs. One advantage of CXTFIT, however, is that it is not affected by personal valuation. Regardless of which method is chosen for the processing of SBDT-data, verifications using the other method are recommended.

\section{Comparison of injection methods}

Results show that SBDTs, and especially the two used injection methods, produce significant results and contribute to the understanding of flow processes in GMWs or even whole aquifers. Although both uniform injection methods deliver the same results, the performance must be assessed in more detail (Table 3). Due to the dilution process, an injection with the PIB takes more time compared to the hosepipe method; however, grinding the salt in advance and minimizing the amount of tracer helps to reduce the dilution time.

Using a hosepipe for uniform injections, usually leads to a more homogeneous tracer concentration over the whole length compared to the PIB, which sometimes produces uneven EC profiles, due to unsteady movement during the dilution process. However, normalizing the data to the first measurement equalizes uneven profiles without losing any information. Using a PIB for the injection reduces the effort of SBDTs significantly and is less time consuming including the preparation. Especially for deep GMWs or boreholes, the hosepipe method requires several tens of liters of tracer solution, which must be prepared and transported to the test site. Furthermore, deep GMWs or boreholes require long hosepipes and, due to their weight, at least two persons or the use of a cable winch.

For multiple GMWs or boreholes with different depths, several hosepipes are needed, otherwise the handling gets very complicated. In contrast, the PIB method demands less preparation and is more flexible, since the permeable bag as well as the cable can be used for several tests and different depth ranges. Also the handling during the injection is easier and can easily be done by one person. 
Fig. 9 Mean apparent filtration velocity from six SBDTs in GMW 7733 with standard deviation. a Results obtained from linear regression. b Results obtained from CXTFIT. For both determination methods, the results show only slight deviations, indicating good reproducibility a) Linear regression

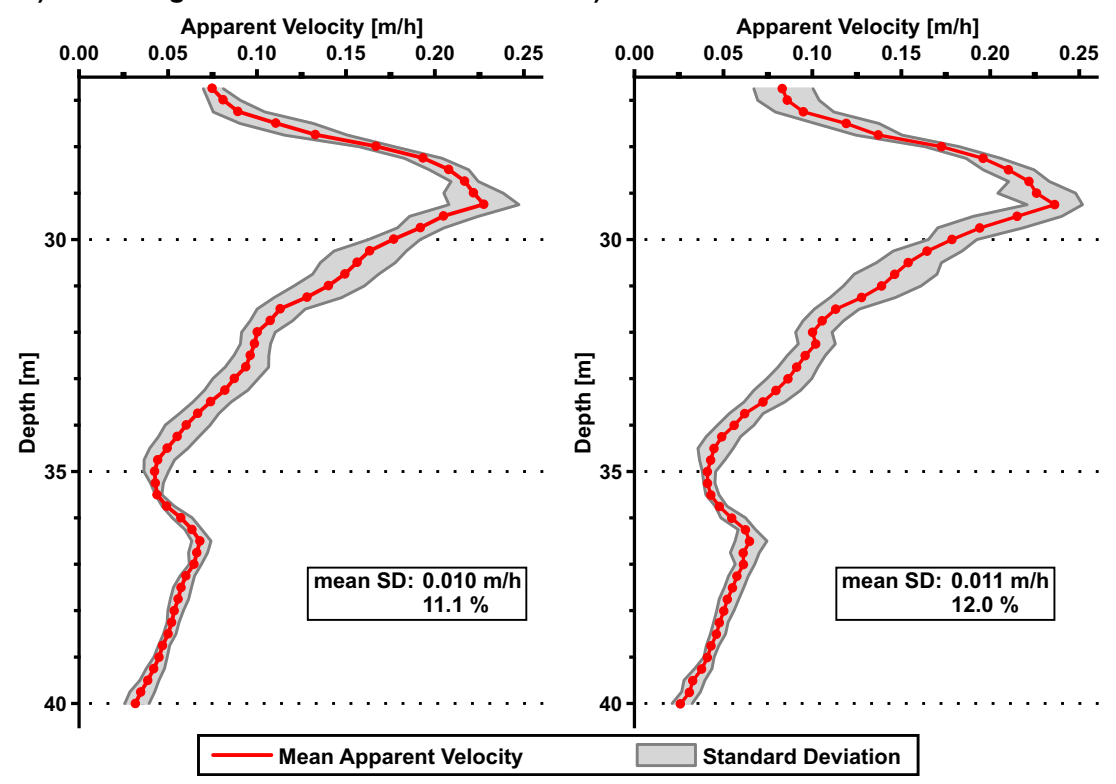

\section{Conclusions}

Compared to other methods such as pumping tests or flowmeter measurements, SBDTs need less equipment and require less effort. Especially, the simplified PIB method is easy to conduct, even by a single person, and only uses commonly available materials, which altogether minimizes costs. However, still meaningful and valuable conclusions about monitoring wells and aquifer properties can be gained, making this method suitable also for low-income countries, projects with limited resources, and study areas with a large number of monitoring wells. Results during this work also demonstrated the reproducibility and flexibility of the simplified method. The PIB method is especially applicable for deep GMWs and difficult accessible testing locations, since no heavy equipment is needed. Further conclusions are:

- The first SBDT in a GMW or borehole should be a uniform injection, since it delivers results for the entire saturated length and leads to a basic understanding of in- or outflow. The injection method should be chosen depending on the depth and the accessibility.

- Results show that increasing the natural background conductivity by a factor of 3-5, or 1,000-2,000 $\mu \mathrm{S} / \mathrm{cm}$, which in this case corresponds to a maximum of $2-3 \mathrm{~g} / \mathrm{L} \mathrm{NaCl}$ in the water column, is sufficiently high to identify flowing features. Also, similar to Lamontagne et al. (2002), no density effects were observed within these limits. In general, tracer use should be minimized to avoid impacts on natural flow conditions and density affecting the interpretation.

- Normalized graphs compensate unequal injections and can be used to separate effects caused by flowing features from methodical influences. Normalizing concentration profiles helps to compare multiple SBDTs conducted in the same GMW or borehole; however, it is not suitable for dominant vertical flow.

- In the absence of vertical flow, both injection methods can be used to calculate horizontal flow within wells or boreholes. For the determination of filtration velocities, both
Table 3 Rating of the injection methods based on field experiences and results $(++$ very good; + good; 0 neutral; deficient)

\begin{tabular}{lll}
\hline Performance criterion & Hosepipe method & Permeable injection bag method \\
\hline Required personnel & 0 & ++ \\
Preparation time & + & ++ \\
Duration of Injection & ++ & + \\
Flexibility (depth range) & - & ++ \\
Deep GMWs or boreholes & - & ++ \\
Handling & + & ++ \\
Homogeneous injection & ++ & + \\
Costs & + & ++ \\
\hline
\end{tabular}


linear regression and CXTFIT provide good results; crossvalidation of individual values can be used for verification. Since the determination of the correction factor $\alpha$, used to convert apparent filtration velocities to filtration velocities, is often not possible due to unknown permeabilities, the apparent filtration velocity can be used to compare different GMWs.

- Despite being conducted in boreholes equipped with slotted casing, all SBDTs could identify the major flowing features in the tested wells.

- SBDTs in the karst aquifer showed the expected wide range of results, with test durations between several hours and multiple weeks. Also, the heterogeneity within each well, e.g. outflow horizons next to inactive segments, could be shown nicely, making SBDTs especially interesting in karst aquifers. In contrast, GMWs in the alluvial aquifer show a more homogeneous behavior and no abrupt changes within the profiles.

Acknowledgements First of all, special thanks go to Dr. Louise Maurice for her support and contributions during this study, especially for her helpful suggestions on field work, the discussions on the interpretation of the results, as well as the language and grammar check. The authors also want to thank Zweckverband Landeswasserversorgung (state water supply), for supporting the work and providing data as well as access to the groundwater monitoring wells in the catchment area. Special thanks goes to Rainer Scheck and Beatrix Wandelt for their support throughout the work. Finally, thanks to Johanna Lundin and Nicole Flanagan for their assistance during field work and data processing. The financial support of the Federal Ministry of Education andResearch (BMBF) and the European Commission through thePartnership for Research and Innovation in the Mediterranean Area(PRIMA) programme under Horizon 2020 (KARMA project, grantagreement number 01DH19022A) is gratefully acknowledged.

Funding Open Access funding enabled and organized by Projekt DEAL.

Open Access This article is licensed under a Creative Commons Attribution 4.0 International License, which permits use, sharing, adaptation, distribution and reproduction in any medium or format, as long as you give appropriate credit to the original author(s) and the source, provide a link to the Creative Commons licence, and indicate if changes were made. The images or other third party material in this article are included in the article's Creative Commons licence, unless indicated otherwise in a credit line to the material. If material is not included in the article's Creative Commons licence and your intended use is not permitted by statutory regulation or exceeds the permitted use, you will need to obtain permission directly from the copyright holder. To view a copy of this licence, visit http://creativecommons.org/licenses/by/4.0/.

\section{References}

Banks EW, Shanafield MA, Cook PG (2014) Induced temperature gradients to examine groundwater flowpaths in open boreholes. Groundwater 52:943-951. https://doi.org/10.1111/gwat.12157

Bense VF, Read T, Bour O, Le Borgne T, Coleman T, Krause S, Chalari A, Mondanos M, Ciocca F, Selker JS (2016) Distributed temperature sensing as a downhole tool in hydrogeology. Water Resour Res 52:9259-9273. https://doi.org/10.1002/ 2016WR018869

Bernstein A, Adar E, Yakirevich A, Nativ R (2007) Dilution tests in a low-permeability fractured aquifer: matrix diffusion effect. Groundwater 45:235-241. https://doi.org/10.1111/j.1745-6584. 2006.00268.x

Brouyère S, Batlle-Aguilar J, Goderniaux P, Dassargues A (2008) A new tracer technique for monitoring groundwater fluxes: the finite volume point dilution method. J Contaminant Hydrol 95:121-140. https://doi.org/10.1016/j.jconhyd.2007.09.001

Chen Z, Auler AS, Bakalowicz M, Bakalowicz M, Drew D, Griger F, Hartmann J, Jiang G, Moosdorf N, Richts A, Stevanovic Z, Veni G, Goldscheider N (2017) The world karst aquifer mapping project: concept, mapping procedure and map of Europe. Hydrogeol J 25: 771-785. https://doi.org/10.1007/s10040-016-1519-3

Cook PG, Herczeg AL, McEwan KL (2001) Groundwater recharge and stream baseflow, Atherton Tablelands, Queensland. Tech Rep 84, CSIRO Land and Water, Canberra, Australia

Drost W, Klotz D, Koch A, Moser H, Neumaier F, Rauert W (1968) Point dilution methods of investigating ground water flow by means of radioisotopes. Water Resour Res 4:125-146. https://doi.org/10. 1029/WR004i001p00125

Fahrmeier N (2016) Hydrogeologische Charakterisierung des Karstgrundwasserleiters im Einzugsgebiet der Landeswasserversorgung [Hydrogeological characterization of the karst aquifer in the catchment area of the State Water Supply Association]. MSc Thesis, Karlsruhe Institute of Technology, Karlsruhe, Germany

Freeze RA, Cherry JA (1979) Groundwater. Prentice-Hall, Englewood Cliffs

Goldscheider N (2005) Karst groundwater vulnerability mapping: application of a new method in the Swabian Alb, Germany. Hydrogeol J 13:555-564. https://doi.org/10.1007/s10040-003-0291-3

Goldscheider N, Drew D (eds) (2007) Methods in karst hydrogeology. Taylor and Francis, Leiden, The Netherlands

Gouze P, Le Borgne T, Leprovost R, Lods G, Poidras T, Pezard P (2008) Non-Fickian dispersion in porous media: 1 . multiscale measurements using single-well injection withdrawal tracer tests. Water Resour Res 44. https://doi.org/10.1029/2007WR006278

Grisak GE, Merritt WF, Williams DW (1977) A fluoride borehole dilution apparatus for groundwater velocity measurements. Can Geotech J 14:554-561. https://doi.org/10.1139/t77-056

Halevy E, Moser H, Zellhofer O, Zuber A (1967) Borehole dilution techniques: a critical review. Isotopes in hydrology. International Atomic Energy Agency (IAEA), Vienna, Austria, pp 531-564

Hall SH (1993) Single well tracer tests in aquifer characterization. Groundw Monit Remediat 13:118-124. https://doi.org/10.1111/j. 1745-6592.1993.tb00443.x

ISO.org (2020) Online browsing platform. https://www.iso.org/obp/ui/\# search/code/. Accessed Nov 2020

Jamin P, Goderniaux P, Bour O, Le Borgne T, Englert A, Longuevergne L, Brouyère $S$ (2015) Contribution of the finite volume point dilution method for measurement of groundwater fluxes in a fractured aquifer. J Contam Hydrol 182:244-255. https://doi.org/10.1016/j. jconhyd.2015.09.002

Klotz D, Moser H, Trimborn P (1979) Single-borehole techniques; present status and examples of recent applications. International Atomic Energy Agency. IAEA, Vienna

Kolokotronis V, Plum H, Prestel R, Schloz W, Rausch R (2002) Hydrogeologische Karte von Baden-Württemberg. Ostalb. Erläuterungen [Hydrogeological map of Baden-Württemberg. Eastern Swabian Alb. Explanations]. Landesamt für Geologie, Rohstoffe und Bergbau Baden-Württemberg, Freiburg Germany; Landesanstalt für Umweltschutz, Baden-Württemberg, Karlsruhe, Germany 
Lamontagne S, Dighton J, Ullman W (2002) Estimation of groundwater velocity in riparian zones using point dilution tests. Technical report 14/02, CSIRO LAND and WATER, Canberra, Australia

Leaf AT, Hart DJ, Bahr JM (2012) Active thermal tracer tests for improved hydrostratigraphic characterization. Groundwater 50:726735. https://doi.org/10.1111/j.1745-6584.2012.00913.x

Libby JL, Robbins GA (2014) An unsteady state tracer method for characterizing fractures in bedrock wells. Groundwater 52:136-144. https://doi.org/10.1111/gwat.12045

Love AJ, Cook PG, Halihan T, Simmons CT (1999) Estimating groundwater flow rates in a fractured rock aquifer, Clare Valley, South Australia. In: Handbook and Proceedings, Water 99 Joint Congress, Brisbane, Australia, July 1999

Love AJ, Cook PG, Simmons CT (2003) Well dilution: a new method to identify flow zones and relative horizontal flow rates in a well. Proc. Int Conf Groundwater Fractured Rocks, Prague, September 2003, IHP-VI Series Groundwater 7, pp 267-268

Maurice L, Barker JA, Atkinson TC, Williams AT, Smart PL (2011) A tracer methodology for identifying ambient flows in boreholes. Ground Water 49:227-238. https://doi.org/10.1111/j.1745-6584. 2010.00708.x

Maurice LD, Atkinson TC, Barker JA, Williams AT, Gallagher AJ (2012) The nature and distribution of flowing features in a weakly karstified porous limestone aquifer. J Hydrol 438-439:3-15. https:// doi.org/10.1016/j.jhydrol.2011.11.050

Palmer CD (1993) Borehole dilution tests in the vicinity of an extraction well. J Hydrol 146:245-266. https://doi.org/10.1016/0022-1694(93) 90279-I

Piccinini L, Fabbri P, Pola M (2016) Point dilution tests to calculate groundwater velocity: an example in a porous aquifer in northeast Italy. Hydrol Sci J 61:1512-1523. https://doi.org/10.1080/ 02626667.2015 .1036756

Pitrak M, Mares S, Kobr M (2007) A simple borehole dilution technique in measuring horizontal ground water flow. Ground Water 45:8992. https://doi.org/10.1111/j.1745-6584.2006.00258.x

Poulsen DL, Cook PG, Simmons CT, Solomon DK, Dogramaci S (2019a) Depth-resolved groundwater chemistry by longitudinal sampling of ambient and pumped flows within long-screened and open borehole wells. Water Resour Res 55:9417-9435. https://doi. org/10.1029/2019WR025713

Poulsen DL, Cook PG, Simmons CT, McCallum J, Noorduijn SL, Dogramaci S (2019b) A constant rate salt tracer injection method to quantify pumped flows in long-screened or open borehole wells. J Hydrol 574:408-420. https://doi.org/10.1016/j.jhydrol.2019.04.051

Read T, Bense V, Bour O, Le Borgne T, Lavenant N, Hochreutener R, Selker JS (2015) Thermal-plume fibre optic tracking (T-POT) test for flow velocity measurement in groundwater boreholes. Geosci Instrum Methods Data Syst Discuss 5:161-175. https://doi.org/10. 5194/gid-5-161-2015

Riemann K, van Tonder G, Dzanga P (2002) Interpretation of single-well tracer tests using fractional-flow dimensions, part 2: a case study. Hydrogeol J 10:357-367. https://doi.org/10.1007/s10040-0020197-5

Schincariol RA, Schwartz FW (1990) An experimental investigation of variable density flow and mixing in homogeneous and heterogeneous media. Water Resour Res 26:2317-2329. https://doi.org/10. 1029/WR026i010p02317

Schloz W, Armbruster V, Prestel R, Weinzierl W (2007) Hydrogeologisches Abschlussgutachten zur Neuabgrenzung des Wasserschutzgebietes Donauried-Hürbe für die Fassungen des Zweckverbandes Landeswasserversorgung im württembergischen Donauried und bei Giengen-Burgberg [Final hydrogeological report on the redefinition of the water protection area Donauried-Hürbe for the extraction wells of the State Water Supply association in the Danube Valley in Württemberg and near Giengen-Burgberg]. Landesamt für Geologie Rohstoffe und Bergbau, Regierungspräsidium Freiburg, Germany

Shafer JM, Brantley DT, Waddell MG (2010) Variable-density flow and transport simulation of wellbore brine displacement. Groundwater 48:122-130. https://doi.org/10.1111/j.1745-6584.2009.00594.x

Šimůnek J, van Genuchten MT, Šejna M, Toride N, Leij FJ (1999) The STANMOD Computer Software for evaluating solute transport in porous media using analytical solutions of convection-dispersion equation. Version 1.0 and 2.0. International Ground Water Modeling Center, Colorado School of Mines, Golden, CO

West LJ, Odling NE (2007) Characterization of a multilayer aquifer using open well dilution tests. Ground Water 45:74-84. https://doi.org/10. 1111/j.1745-6584.2006.00262.x

Williams A, Bloomfield J, Griffiths K, Butler A (2006) Characterising the vertical variations in hydraulic conductivity within the Chalk aquifer. J Hydrol 330:53-62. https://doi.org/10.1016/j.jhydrol.2006.04. 036

Yang M, Antonio Yaquian J, Annable MD, Jawitz JW (2019) Karst conduit contribution to spring discharge and aquifer crosssectional area. J Hydrol 578:124037. https://doi.org/10.1016/j. jhydrol.2019.124037

Publisher's note Springer Nature remains neutral with regard to jurisdictional claims in published maps and institutional affiliations. 